\title{
Perbandingan Efektivitas Daya Hambat Kotrimoksazol Generik dan Paten terhadap Pertumbuhan Bakteri Escherichia coli sebagai Penyebab Infeksi Saluran Kemih secara In Vitro
}

\author{
Puti Anggun Sari ${ }^{1}$, Erly $^{2}$, Dessy Arisanty $^{3}$
}

\begin{abstract}
Abstrak
Infeksi saluran kemih merupakan salah satu infeksi yang sering ditemukan setelah infeksi saluran napas. Penyebab terbanyak infeksi saluran kemih adalah Escherichia coli. Kotrimoksazol merupakan kombinasi dari dua obat yaitu trimetoprim dan sulfametoksazol serta salah satu contoh antibiotik yang merupakan first-line therapy untuk infeksi saluran kemih. Kotrimoksazol terbagi menjadi dua jenis obat yaitu obat generik dan paten. Akan tetapi, belakangan ini penggunaan obat generik mulai menurun di masyarakat dan masyarakat cenderung meragukan kualitasnya. Padahal masyarakat yang akan diuntungkan jika mengetahui mutu obat generik tidak kalah dengan obat paten. Tujuan dari penelitian ini adalah untuk membandingkan efektivitas daya hambat kotrimoksazol generik dan paten terhadap pertumbuhan bakteri Escherichia coli sebagai penyebab infeksi saluran kemih secara in vitro. Penelitian ini merupakan penelitian analitik eksperimental dengan desain cross-sectional study. Penelitian ini menggunakan 19 sampel isolat bakteri dari pasien infeksi saluran kemih yang disebabkan oleh Escherichia coli di RSUP Dr. M. Djamil yang ditentukan rumus minimal adequate sample size menggunakan metode difusi cakram dan dilihat perbandingan antara zona bebas kuman yang dibentuk oleh obat generik dan paten tersebut. Data yang diperoleh akan diolah secara statistik dengan uji hipotesis t-independent test. Hasil penelitian menunjukkan bahwa pada 17 sampel tidak didapatkan zona bebas kuman baik pada kotrimoksazol generik atau paten. Sedangkan pada 2 sampel lainnya didapatkan zona bebas kuman pada kedua obat kotrimoksazol generik dan paten. Setelah dilakukan analisis statistik menggunakan SPSS dengan uji t-independent test didapatkan bahwa tidak terdapat perbedaan bermakna antara sensitivitas bakteri Escherichia coli penyebab infeksi saluran kemih terhadap kotrimoksazol generik dan paten. Sedangkan resistensi yang terjadi pada 17 sampel lain diduga disebabkan penggunaan antibiotika yang meluas dan tidak tepat baik di rumah sakit maupun di kalangan masyarakat.
\end{abstract}

Kata kunci: Escherichia coli, infeksi saluran kemih, sensitivitas, antibiotika, generik, paten

\begin{abstract}
Urinary tract infection is one of the infections that are often found after a respiratory tract infection. The major cause of urinary tract infections is Escherichia coli. Co-trimoxazole is a combination of two drugs trimethoprim and sulfamethoxazole. Co-trimoxazole is one of the examples of a first - line therapy antibiotic for urinary tract infections. As with other drugs, co-trimoxazole is divided into two types of drugs which are generic and patent drugs. However, recently the use of generic drug in the community began to decrease and people tend to doubt its quality. Whereas it is the community that will be benefited if they found out that the quality of generic drug is not inferior to the patent drug. The aim of this study was to compare the effectiveness of generic and patents co-trimoxazole inhibition on the growth of the bacteria Escherichia coli as a cause of urinary tract infection in in vitro. This study is an analytical experimental with cross-sectional study design. This study used 19 isolated-bacterial from infected-urinary tract patients which were caused by Escherichia coli in Dr. M. Djamil Hospital. These samples specified by minimal adequate sample size and using disc diffusion method. Then they were observed the comparison between germ-free zone established by the generic and the patent drugs. Data obtained will be treated statistically with t-independent hypothesis test.The results
\end{abstract}


showed that 17 samples didn't have germ-free zone both in generic and patent co-trimoxazole. While two sample others which have germ-free zone were obtained both in generic or patent co-trimoxazole. According to SPSS statistical analysis with t- independent test showed that there was no significant difference between the sensitivity of Escherichia coli as a cause of urinary tract infections to generic and patent co-trimoxazole. Whereas resistance occurred in 17 other samples were suspected to be caused widespread and irrational use of antibiotics both in hospitals and in the community.

Keywords: Escherichia coli, urinary tract infections, sensitivity, antibiotic, generic, patent

\author{
Affiliasi penulis : 1. Pendidikan Dokter FK UNAND (Fakultas \\ Kedokteran Universitas Andalas Padang), 2. Bagian Mikrobiologi \\ FK UNAND, 3. Bagian Biokimia FK UNAND \\ Korespondensi : Puti Anggun Sari, E-mail : putianggun@ymail.com, \\ Telp: 08128300092
}

\section{PENDAHULUAN}

Penyakit infeksi masih merupakan masalah kesehatan dunia, baik di negara berkembang maupun di negara maju. ${ }^{1}$ Indonesia merupakan salah satu negara dimana penyakit infeksi merupakan masalah kesehatan yang penting. Salah satunya adalah infeksi saluran kemih. Infeksi saluran kemih merupakan salah satu penyakit infeksi kedua terbanyak yang sering ditemukan setelah infeksi saluran napas. ${ }^{2}$

Infeksi saluran kemih adalah istilah umum yang menunjukkan keberadaan mikroorganisme di dalam urin. Pada individu yang normal urin selalu steril dari mikroorganisme. ${ }^{3}$ Sebagian besar infeksi saluran kemih terjadi karena masuknya mikroorganisme melalui uretra. Mikroorganisme tersebut melakukan invasi asending dari uretra ke kandung kemih, bahkan bisa sampai ke ginjal. Mikroorganisme tersebut antara lain Escherichia coli, Klebsiella sp., Proteus mirabilis, Enterobacter sp., Pseudomonas aeurginosa, Staphylococcus saprophyticus, dan Staphylococcus aureus. $^{2}$ Escherichia coli merupakan bakteri yang paling sering diisolasi dari pasien dengan infeksi simtomatik maupun asimtomatik. $^{3}$

Infeksi saluran kemih merupakan infeksi yang sering ditemukan di praktik umum, walaupun bermacam-macam antibiotika sudah banyak tersedia di pasaran. ${ }^{3}$ Kotrimoksazol adalah salah satu contoh antibiotik yang merupakan first-line therapy untuk infeksi saluran kemih. ${ }^{2}$ Kotrimoksazol merupakan kombinasi dari dua obat yaitu trimetoprim dan sulfametoksazol. ${ }^{4}$ Pada Daftar Obat Esensial Nasional 2011, kotrimoksazol merupakan salah satu dari obat yang tercantum. Dimana Daftar Obat Esensial
Nasional ialah daftar obat terpilih yang paling dibutuhkan dan yang diupayakan tersedia di unit pelayanan kesehatan sesuai dengan fungsi dan tingkatnya. Dari sumber yang sama juga didapatkan bahwa dari sisi medis, obat esensial sedikit banyak dapat dikaitkan dengan drug of choice. ${ }^{5}$

Berkaitan dengan antibiotik kotrimoksazol yang merupakan first-line therapy untuk infeksi saluran kemih, didapatkan dari The New England Journal of Medicine yang berjudul Uncomplicated Urinary Tract Infection pada tahun 2012 bahwa tingkat resistensi kotrimoksazol untuk infeksi saluran kemih yang disebabkan oleh Escherichia coli telah mencapai angka 20\%. Tingkat resistensi tersebut dapat berbeda di setiap wilayah dan Negara. ${ }^{6}$

Sebenarnya terdapat beberapa istilah yang berkaitan dengan obat yang umum dipakai, salah satu contohnya ialah obat paten. Menurut buku yang diterbitkan oleh Badan Pengawas Obat dan Makanan, obat paten dirumuskan sebagai obat jadi dengan nama dagang yang terdaftar atas nama pembuat atau yang dikuasakannya, dan dijual dalam bungkus asli dari pabrik (SK Menkes No.193/Kab/B.VII/71 tanggal 21 Agustus 1972). Selain itu juga ada istilah obat generik, yaitu obat dengan nama resmi yang telah ditetapkan dalam Farmakope Indonesia dan International Nonproprietary Names dari WHO untuk zat kimia yang dikandungnya. Begitu juga dengan obat esensial yang dapat disediakan dalam bentuk obat generik maupun obat dengan nama dagang atau obat paten. ${ }^{7}$

Setiap obat paten atau obat dengan nama dagang akan melakukan promosi untuk masingmasing produknya, maka harga obat paten umumnya lebih mahal. ${ }^{5}$ Harga yang lebih mahal pada obat paten juga dipengaruhi oleh penyediaan dan pembuatannya sehingga warna dan kemasan terlihat lebih menarik dibandingkan obat generik. Beberapa obat paten terdapat juga bahan tambahan lain seperti zat yang 
dapat mengurangi reaksi alergi seseorang terhadap zat aktif yang dikandung oleh obat tersebut. ${ }^{8}$ Kebijakan obat generik merupakan salah satu kebijakan untuk mengendalikan harga obat. Latar belakang kebijakan pemerintah untuk menyediakan obat generik diantaranya ialah karena tingginya harga obat-obat yang harus ditebus di apotek, yang sering kali menyebabkan masyarakat melakukan pembelian obat hanya separuh dari yang seharusnya. ${ }^{7}$ Namun, sekarang ini terdapat kecenderungan bahwa penggunaan obat generik mulai menurun. Banyak masyarakat yang memandang obat generik sebagai obat kelas dua dan cendrung meragukan kualitasnya. ${ }^{9}$ Untuk itu hasil dari pemeriksaan mutu dan informasi mengenai obat generik harus selalu diinformasikan kepada pemberi pelayanan kesehatan maupun masyarakat luas.

\section{METODE}

Penelitian ini merupakan penelitian analitik eksperimental dengan desain cross-sectional untuk mengetahui perbandingan efektivitas daya hambat kotrimoksazol generik dan paten terhadap pertumbuhan bakteri Escherichia coli sebagai penyebab infeksi saluran kemih secara in vitro. Populasi penelitian adalah semua isolat bakteri yang berasal dari pasien infeksi saluran kemih yang datang untuk pemeriksaan urin di Laboratorium Mikrobiologi RSUP Dr. M. Djamil Padang. Sampel dalam penelitian ini adalah semua isolat bakteri pasien infeksi saluran kemih yang datang untuk pemeriksaan urin di Laboratorium Mikrobiologi RSUP Dr. M. Djamil Padang yang disebabkan oleh Escherichia coli. Data dari hasil penelitian akan dianalisis menggunakan analisis univariat dan bivariat dengan uji hipotesis $t$ independent test.

\section{HASIL DAN PEMBAHASAN}

Penelitian yang telah dilakukan dari November 2013 - Maret 2014 mendapatkan 19 sampel isolat bakteri Escherichia coli dari pasien yang melakukan pemeriksaan urin di Laboratorium Mikrobiologi RSUP Dr. M. Djamil. Dari 19 sampel tersebut, didapatkan 17 sampel resisten terhadap kedua antibiotika baik kotrimoksazol generik maupun paten. Berikut adalah hasil yang diperoleh:

TABEL

Tabel 1. ReRata Zona Bebas Kuman Escherichia coli Sebagai Penyebab Infeksi Saluran Kemih Setelah Pemberian Antibiotika Generik.

\begin{tabular}{rcccc}
\hline \multirow{2}{*}{ No. } & \multicolumn{4}{c}{ Zona Bebas Kuman (mm) } \\
\cline { 2 - 5 } & \multicolumn{4}{c}{ Kotrimoksazol } \\
\cline { 2 - 5 } & $\begin{array}{c}\text { Pengulang } \\
\text { an ke-1 }\end{array}$ & $\begin{array}{c}\text { Pengulang } \\
\text { an ke-2 }\end{array}$ & $\begin{array}{c}\text { Pengulang } \\
\text { an ke-3 }\end{array}$ & $\begin{array}{c}\text { Rata- } \\
\text { Rata }\end{array}$ \\
\hline 1. & - & - & - & - \\
2. & - & - & - & - \\
3. & - & - & - & - \\
4. & - & - & - & - \\
5. & - & - & - & - \\
6. & - & - & - & - \\
7. & - & - & - & - \\
8. & - & - & - & - \\
9. & - & - & - & - \\
10. & 32 & 35 & 38 & 35 \\
11. & - & - & - & - \\
12. & - & - & - & - \\
13. & - & - & - & - \\
14. & 31 & 28 & 30 & 29,6 \\
15. & - & - & - & - \\
16. & - & - & - & - \\
17. & - & - & - & - \\
18. & - & - & - & - \\
19. & - & - & - & - \\
\hline & Rata-Rata Zona Bebas Kuman (mm) & 32,3 \\
\hline & & & & - \\
\hline
\end{tabular}

Tabel 1 memperlihatkan bahwa 17 dari 19 sampel isolat bakteri telah mengalami resisten terhadap antibiotika kotrimoksazol generik. Sedangkan pada dua sampel lainnya didapatkan rata-rata zona bebas kuman sebesar 32,3 $\mathrm{mm}$.

Tabel 2 memperlihatkan bahwa 17 dari 19 sampel isolat bakteri telah mengalami resisten terhadap antibiotika kotrimoksazol paten. Sedangkan pada dua sampel lainnya didapatkan rata-rata zona bebas kuman sebesar 32,1 $\mathrm{mm}$.

Dari tabel 1 dan 2 terlihat bahwa sensitivitas bakteri Escherichia coli penyebab infeksi saluran kemih terhadap kotrimoksazol generik maupun paten pada 17 sampel tidak didapatkan diameter zona bebas kuman yang menurut standar CLSI (Clinical and Laboratory Standards Institute) termasuk dalam kriteria resisten karena diameter $\leq 11 \mathrm{~mm}$. Sedangkan pada dua sampel lainnya pada kedua jenis obat didapatkan rata-rata diameter zona bebas kuman $\geq 16 \mathrm{~mm}$ yang menurut standar CLSI termasuk dalam kriteria sensitif. ${ }^{11}$ 
Tabel 2. Rerata Zona Bebas Kuman Escherichia coli Sebagai Penyebab Infeksi Saluran Kemih Setelah Pemberian Antibiotika Paten.

\begin{tabular}{|c|c|c|c|c|}
\hline \multirow{3}{*}{ No } & \multicolumn{4}{|c|}{ Zona Bebas Kuman (mm } \\
\hline & \multicolumn{4}{|c|}{ Kotrimoksazol } \\
\hline & $\begin{array}{c}\text { Pengula } \\
\text { ngan ke- } \\
1\end{array}$ & $\begin{array}{c}\text { Pengulanga } \\
\text { n ke-2 }\end{array}$ & $\begin{array}{c}\text { Pengulanga } \\
\text { n ke-3 }\end{array}$ & Rata-Rata \\
\hline \multicolumn{5}{|l|}{1} \\
\hline \multicolumn{5}{|l|}{2} \\
\hline \multicolumn{5}{|l|}{3} \\
\hline \multicolumn{5}{|l|}{4} \\
\hline \multicolumn{5}{|l|}{5} \\
\hline \multicolumn{5}{|l|}{6} \\
\hline \multicolumn{5}{|l|}{7} \\
\hline \multicolumn{5}{|l|}{8} \\
\hline \multicolumn{5}{|l|}{9} \\
\hline 10 & 33 & 34 & 32 & 33 \\
\hline \multicolumn{5}{|l|}{11} \\
\hline \multicolumn{5}{|l|}{12} \\
\hline \multicolumn{5}{|l|}{13} \\
\hline 14 & 31 & 32 & 31 & 31,3 \\
\hline \multicolumn{5}{|l|}{15} \\
\hline \multicolumn{5}{|l|}{16} \\
\hline \multicolumn{5}{|l|}{17} \\
\hline \multicolumn{5}{|l|}{18} \\
\hline \multicolumn{5}{|l|}{19} \\
\hline \multicolumn{5}{|l|}{20} \\
\hline Rata & ata Zona B & oas Kuman ( $\mathrm{m}$ & & 32,1 \\
\hline
\end{tabular}

Dari kedua tabel tersebut juga didapatkan persentase resistensi bakteri Echerichia coli terhadap kotrimoksazol sebesar 89,47\%. Resistensi memiliki arti tidak terhambatnya pertumbuhan bakteri dengan pemberian antibiotik dengan dosis normal yang seharusnya atau kadar hambat minimalnya. ${ }^{10}$ Pernyataan mengenai sudah meningkatnya resistensi terhadap antibiotika lini pertama sesuai dengan penelitian Antimicrobial Resistant in Indonesia (AMRIN-study) yang mengatakan bahwa tingkat resistensi antibiotika awalnya tinggi di rumah sakit, namun lambat laun terdapat peningkatan resistensi antibiotika di kalangan masyarakat. Berdasarkan penelitian tersebut juga disebutkan dari 781 pasien yang dirawat di rumah sakit didapatkan $81 \%$ Escherichia coli telah resisten terhadap berbagai antibiotika, salah satunya yang telah resisten terhadap kotrimoksazol sebesar 56\%. Sedangkan untuk resistensi di kalangan masyarakat didapatkan dari 2494 individu 43\% Escherichia coli telah resisten terhadap berbagai antibiotika contohnya kotrimoksazol sebesar 29\%. ${ }^{12}$ Penelitian yang berjudul Uncomplicated Urinary Tract Infection menyebutkan juga bahwa resistensi Escherichia coli terhadap kotrimoksazol meningkat sampai dengan $20 \%$ di berbagai tempat. $^{6}$

Timbulnya resistensi terhadap antibiotika dipengaruhi oleh beberapa faktor dimana yang tersering adalah penggunaan antibiotika yang meluas dan tidak tepat. Resistensi tersebut muncul karena penggunaan yang terlalu singkat, dosis terlalu rendah, dan diagnosis awal yang tidak tepat. Banyak juga pasien yang membeli antibiotika tanpa resep dari dokter (self-medication). Faktor lain yang dapat menimbulkan resistensi antibiotika adalah seringnya regimen terapi tidak terselesaikan dikarenakan keterbatasan biaya. ${ }^{10}$

Resistensi terhadap antibiotika tidak luput dari faktor yang berasal dari bakterinya sendiri. Perubahanperubahan genetik yang terjadi pada bakteri dapat menyebabkan bakteri yang awalnya sensitif terhadap suatu antibiotika menjadi kurang peka bahkan tidak peka sama sekali atau resisten. Contoh dari perubahan-perubahan genetik dapat terjadi melalui mutasi seperti multi-drug resistance pada Mycobacterium tuberculosis. Di samping itu, perubahan genetik juga dapat terjadi melalui transposon dan integron. Mekanisme tersebut menyebabkan gen pembawa (plasmid) menyatu ke dalam kromosom bakteri sehingga resistensi yang terjadi menetap bahkan dapat diturunkan ke generasi berikutnya. $^{13}$ Resistensi tersebut dapat muncul dari satu atau beberapa mekanisme sebagai berikut seperti 
bakteri mensintesis suatu enzim inaktivator atau penghancur antibiotika, bakteri mengubah permeabilitasnya terhadap obat, dan bakteri melakukan suatu perubahan struktur sasaran bagi obat. Selain itu mekanisme lain adalah bakteri mengubah jalur metabolik yang akan dihambat obat ataupun bakteri mengembangkan perubahan enzim yang tetap dapat melakukan fungsi metabolismenya tetapi lebih sedikit dipengaruhi oleh obat dari pada enzim pada kuman yang rentan. ${ }^{10}$

Tabel 3. Perbandingan Rerata Daya Hambat Kotrimoksazol Generik dan Paten(mm)

\begin{tabular}{cccccc}
\hline & Rerata & SD & Min & Max & P \\
\hline $\begin{array}{c}\text { Kotrimoksazol } \\
\text { Generik }\end{array}$ & 32,33 & 3,61 & 28 & 38 & \\
\cline { 1 - 4 } $\begin{array}{c}\text { Kotrimoksazol } \\
\text { Paten }\end{array}$ & 32,16 & 1,16 & 31 & 34 & \\
\hline
\end{tabular}

Tabel 3 memperlihatkan data hasil penelitian yang telah dianalisis dengan uji hipotesis t-independent test dengan derajat kepercayaan sebesar 95\% dan $p \geq$ 0,05 yaitu tidak terdapat perbedaan yang bermakna antara daya hambat kotrimoksazol generik dan paten terhadap pertumbuhan bakteri Escherichia coli sebagai penyebab infeksi saluran kemih secara in vitro. Hal tersebut dapat terjadi karena zat aktif yang dikandung di dalam kedua obat tersebut sama, hanya saja pada obat paten terdapat bahan tambahan lainnya. Salah satu contoh dari bahan tambahan lain dari obat paten adalah adanya zat yang dapat mengurangi reaksi alergi seseorang terhadap zat aktif yang dikandungnya. Perbedaan dari kedua jenis obat yaitu generik dan paten terletak pada harganya, dimana harga obat paten lebih mahal dari obat generik. Harga obat paten lebih mahal dari obat generik karena dibutuhkan biaya untuk penelitian dan promosi obat tersebut .

\section{KESIMPULAN}

Tidak terdapat perbedaan yang bermakna antara efek daya hambat kotrimoksazol generik dan paten terhadap pertumbuhan bakteri Escherichia coli sebagai penyebab infeksi saluran kemih secara in vitro.

\section{UCAPAN TERIMA KASIH}

Ucapan terima kasih kepada dr. Erly, Sp.MK dan Dessy Arisanty, S.Si, M.Sc yang telah banyak mengorbankan waktu, pikiran dan tenaga dalam memberikan arahan dan masukan dalam penelitian ini.

\section{DAFTAR PUSTAKA}

1. Kuntaman, Eddy Mudihardi, Setio Harsono, Kartuti Debora, Ni Made Mertaniasih. Aspek Mikrobiologi dalam Infeksi Saluran Kemih. Dalam: Nasronudin, Usman Hadi, editor (penyunting). Penyakit Infeksi di Indonesia Solusi Kini dan Mendatang. Surabaya: Airlangga University Press; 2007. hlm 166-70.

2. Porth, Carol Mattson, Glenn Matfin. Pathophysiology Concepts of Altered Health States. Edisi ke-8. Philadelphia: Lippincott Williams \& Wilkins; 2008.

3. Sukandar, Enday. Infeksi Saluran Kemih Pasien Dewasa. Dalam: Sudoyo Aru W., Bambang Setiyohadi, Idrus Alwi, Marcellus, Siti Setiati, editor (penyunting). Buku Ajar IImu Penyakit Dalam. Jakarta: Internal Publishing; 2009. hlm 1008-14.

4. Gunawan, Sulistia Gan. Farmakologi dan Terapi. Jakarta: Balai Penerbit Fakultas Kedokteran Universitas Indonesia; 2009.

5. Badan Pengawas Obat dan Makanan. Informatorium Obat Nasional Indonesia Badan Pengawas Obat dan Makanan Republik Indonesia. Jakarta: Sagung Seto; 2009.

6. The New England Journal of Medicine. Uncomplicated Urinary Tract Infection. 2012; 366:1028-37.

7. Rahardjo, Rio. Kumpulan Kuliah Farmakologi. Jakarta: EGC; 2009.

8. Salingga, Indra. Obat Generik : Don't Judge It by The Name! Bandung: Chem ITB article; 2011.

9. Departemen Kesehatan Republik Indonesia. Obat Generik Pilihan Terbaik dengan Harga Terjangkau [serial online] 2010 (Diunduh 8 Juni 2013). Tersedia dari: URL: HYPERLINK http://www.depkes.go.id/downloads/advertoria 
l/adv obat generik.pdf

10. Utami, Eka Rahayu. Antibiotika, Resistensi, dan Rasionalitas Terapi. Artikel. Fakultas Sains dan Teknologi UIN Maliki Malang; 2012.

11. Clinical and Laboratory Standards Institute. 2007. Disk Diffusion Supplemental Tables.
Pennsylvania: CLSI; 2007.

12. Peraturan Menteri Kesehatan Republik Indonesia. Pedoman Umum Penggunaan Antibiotika. Jakarta: Depkes RI; 2011.

13. Yenny, Elly Herwana. Resistensi dari Bakteri Enterik: Aspek Global terhadap Antimikroba. Universa Medicina. 2007; 26: 46-56. 